\title{
BIOPSYCHOSOCIAL DETERMINANTS OF DIABETES MELLITUS TYPE 2: EVIDENCE FROM SURAKARTA, CENTRAL JAVA
}

\author{
Anggi Putri Aria Gita'), Isna Qadrijati²), Bhisma Murti1) \\ ${ }^{1)}$ Masters Program in Public Health, Universitas Sebelas Maret \\ 2)Faculty of Medicine, Universitas Sebelas Maret
}

\begin{abstract}
Background: Stress has been shown to have major effects on metabolic activity. Diabetes mellitus (DM) is a metabolic disease characterized by chronic hyperglycemia that results from an alteration of the secretion or action of insulin. This study aimed to investigate biopsychosocial determinants of diabetes mellitus type 2

Subjects and Method: A case control study was conducted in Surakarta, Centra Java, Indonesia, from November 2019 to January 2020. A sample of 200 patients with type 2 DM was selected by fixed disease sampling. The dependent variable was type 2 DM. The independent variables were family history of DM, dietary pattern, physical activity, body mass index (BMI), central obesity, stress, hypertension, and smoking. The data were collected by medical record and questionnaire. The data were analyzed by a multiple logistic regression run on Stata 13.

Results: The risk of type $2 \mathrm{DM}$ increased with family history of tipe $2 \mathrm{DM}(\mathrm{OR}=12.88 ; 95 \%$ $\mathrm{CI}=5.18$ to $32.04 ; \mathrm{p}<0.001)$, poor dietary pattern $(\mathrm{OR}=2.92 ; 95 \% \mathrm{CI}=1.16$ to $7.36 ; \mathrm{p}=$ $0.023)$, and low physical activity $(\mathrm{OR}=3.15 ; 95 \% \mathrm{CI}=1.22$ to $8.18 ; \mathrm{p}=0.018)$, central obesity $(\mathrm{OR}=4.55 ; 95 \% \mathrm{CI}=1.55$ to $13.41 ; \mathrm{p}=0.006)$, stress $(\mathrm{OR}=3.07 ; 95 \% \mathrm{CI}=1.21$ to $7.79 ; \mathrm{p}=$ 0.018), history of hypertension $(\mathrm{OR}=3.83 ; 95 \% \mathrm{CI}=1.49$ to $9.79 ; \mathrm{p}=0.005)$, and smoking behavior $(\mathrm{OR}=3.86 ; 95 \% \mathrm{CI}=1.29$ to $11.57 ; \mathrm{p}=0.016)$. The risk of type $2 \mathrm{DM}$ decreased with normal BMI (OR=0.37; 95\% CI= 0.13 to 1.01 ; $\mathrm{p}=0.053$ ).

Conclusion: The risk of type 2 DM increases with family history of tipe $2 \mathrm{DM}$, poor dietary pattern, and low physical activity, central obesity, stress, history of hypertension, and smoking behavior. The risk of type 2 DM decreases with normal BMI.
\end{abstract}

Keywords: Determinan biopsikososial, DM tipe 2.

Correspondence:

Anggi Putri Aria Gita. Masters Program in Public Health, Universitas Sebelas Maret, Jl. Ir. Sutami 36A, Surakarta 57126, Central Java, Indonesia. Email: anggipag@gmail.com. Mobile: +628975406464 .

The $7^{\text {th }}$ International Conference on Public Health Solo, Indonesia, November 18-19, 2020 | 91 https://doi.org/10.26911/the7thicph.01.46 